\title{
Study on Mortality and Recruitment Pattern of Etroplus suratensis (Bloch, 1790) from Chilika Lagoon, Odisha, India
}

\author{
B.R. Samantaray ${ }^{*}$, S.K. Bhuyan ${ }^{2}$, S.K. Misra ${ }^{2}$ and D. Sathpathy ${ }^{2}$ \\ ${ }^{1}$ KVK, Mayurbhanj-1, OUAT, Odisha, India \\ ${ }^{2}$ College of Fisheries, OUAT, Rangeilunda, Odisha, India \\ *Corresponding author
}

A B S T R A C T

\begin{tabular}{|l|}
\hline Ke y w o r d s \\
Mortality, \\
Recruitment \\
pattern, Etroplus \\
suratensis, Chilika \\
\hline Article Info \\
\hline Accepted: \\
07 January 2019 \\
Available Online: \\
10 February 2019 \\
\hline \hline
\end{tabular}

\section{Introduction}

The Chilika lagoon is the largest brackish water lakes of the Aisa, a Ramsar site. Chilika lagoon is a unique assemblage of marine, brackish and fresh water ecosystem with estuarine characters. It is one of the hotspots of biodiversity and shelters a number of endangered species. The highly productive lagoon ecosystem with its rich fishery resources sustains the livelihood of more than 150,000 fishers who live in and around the Lagoon. Pearl spot (Etroplus suratensis), also known as green chromide is widely found in the freshwater and brackish water ecosystems
Mortality and recruitment pattern of Etroplus suratensis (Bloch, 1790) from Chilika Lagoon, Odisha was studied using length-frequency based analysis to evaluate the length at age, mortality rates and recruitment pattern. The study revealed that the total mortality, $\mathrm{Z}(2.265 / \mathrm{yr})$ natural mortality, M (0.87/yr) and fishing mortality, F (1.3/yr). The present study also revealed that the probability of capture at $\mathrm{L}_{25}, \mathrm{~L}_{50}$ and $\mathrm{L}_{75}$ as 19.06 $\mathrm{cm}, 21.75 \mathrm{~cm}$ and $24.45 \mathrm{~cm}$ respectively and $\mathrm{E}_{10}, \mathrm{E}_{50}$ and $\mathrm{E}_{\max }$ as $0.504,0.322$ and 0.649 respectively. The study of the recruitment patterns of E. suratensis also revealed of two annual recruitment.

of India and Sri lanka ${ }^{(1)}$. It is endemic to peninsular India extending from South Canara to Malabar on the west coast to Chilka lake on the east coast ${ }^{(2)}$. It is also one of the most popular and very important fish species in Chilika lagoon. This fish is locally known as Kundala and has its economic importance and larger sizes are mostly exported. From the last 10 year studies conducted by Chilika Development Authority (CDA) the average contribution of Etroplus suratensis is about 271.056 tons from 2008-09 to 2012-13 and the catches vary greatly during the last ten year ${ }^{(3)}$. However the stock assessment study of E. suratensis in the lagoon is very limited. 
Therefore in the present study was carried out to evaluate the length at age, mortality rates and recruitment pattern, estimate the age and growth parameters of $E$. suratensis species.

\section{Materials and Methods}

In the present study, length based stock assessment method is used and length frequency data of E. suratensis species were collected from the major landing centre i.e Balugaon, Sorana and Nairi. The data on individual length and weight of the samples were measured and the total catch of the species were noted on the day of observation. Total length was measured in mm using the measuring board and the weight was measured in gm using a digital balance with corresponding length. The length frequency data was distributed in $10 \mathrm{~mm}$ class intervals for the study of growth and the sample was raised for the day and subsequently for the month following the method of Sekharan ${ }^{(4)}$.

In the present study the pooling of more than one year data, September, 2016-February 2018 was taken into account during the result analysis. Length-frequency data of more than one year was also reported by a number of scientists ${ }^{(5,6,7,8)}$. Data were analyzed using the FiSAT-II (FAO-ICLARM Stock Assessment Tools $)^{9}$ in the computer software package. Additional estimate of Prediction of the maximum length from the extreme values of Etroplus suratensis in Chilika lagoon was also carried out. The growth performance $(\varnothing)$ in terms of length growth was calculated by FISAT-II using the parameters L $\infty$ and $\mathrm{K}$ and also using index ${ }^{(10)}$ as per the formula give below

$\emptyset=\left\{=\log 10 \mathrm{~K}+2 \log 10 \mathrm{~L}_{\infty}\right\}$

Total mortality $(Z)$ was estimated using the length converted catch curve method as implemented in ELEFAN I. Natural mortality rate (M) was estimated using Pauly's empirical relationship (11) as mentioned, below.

$\log _{10} M=-0.0066-0.279 \log _{10} \mathrm{~L}_{\infty}+$
$0.6543 \log _{10} \mathrm{~K}+0.4634 \log _{10} \mathrm{~T}$ where, $\mathrm{L}_{\infty}$ is expressed in $\mathrm{cm}$ and $\mathrm{T}$, the mean annual environmental temperature in ${ }^{\circ} \mathrm{C}$ which is here $29^{\circ} \mathrm{C}$.

Fishing mortality (F) was obtained by subtracting $\mathrm{M}$ from $\mathrm{Z}$ and exploitation rate (E) was obtained from $\mathrm{F} / \mathrm{Z}[\mathrm{E}=\mathrm{F} / \mathrm{Z}=\mathrm{F} /$ $(\mathrm{F}+\mathrm{M})]$ (12). Recruitment patterns were obtained by backward projection on the length axis of a set of length-frequency data as described in the FiSAT-II routine. Probability of capture, size at first capture $\left(\mathrm{L}_{\mathrm{c}}\right)$ and recruitment pattern was also obtained by means of ELEFAN I.

Estimation of recruitment pattern analysis was carried out using the length frequency raised data using the FiSAT-II (FAO-ICLARM Stock Assessment Tools).

\section{Results and Discussion}

\section{Growth parameters}

Growth parameters of von Bertalanffy growth formula viz $\mathrm{L}_{\infty}$ and $\mathrm{K}$ were analysed by FISAT-II for E. suratensis in Chilika lagoon and the values of $\mathrm{L}_{\infty}$ and $\mathrm{K}$ was estimated at $24.78 \mathrm{~cm}$ and $0.30 / \mathrm{yr}$ respectively with the response surfaces $(\mathrm{Rn})$ used for the curves was 0.237. The growth parameter was estimated through ELEFAN-1 (Fig. 1).

It was also found in his study ${ }^{(13)}$ on Cichlidae inhabiting lake Manzala, Egypt also found the range of $L_{\infty}$ value between (21.53 -28.88) and $\mathrm{K}$ value between $(0.27-059)$. The value of growth curvature $(\mathrm{K})$ also found between $0.12-0.23 / \mathrm{yr}^{(21)}$. 


\section{Mortality}

Total mortality ' $Z$ ' was calculated from the length converted catch curves in FISAT-II where $\mathrm{L} \infty(24.78 \mathrm{~cm})$ and $\mathrm{K}(0.3 / \mathrm{yr})$ as input value.

The estimated values of total mortality (Z) were found as 2.2/year using the Jones and Van Zalinge Plot. The natural mortality rate
' $M$ ' was estimated from Pauly's empirical equation (Fig. 2). It was calculated as $0.869 / \mathrm{yr}^{22}$. The fishing mortality rate was estimated by subtracting ' $M$ ' from ' $Z$ '. Thus the values of $F$ obtained as 1.76 . From the present study as the value of $\mathrm{Z} / \mathrm{K}$ more than 2 indicating mortality was predominant over growth and the stock was mortality dominated which corroborate the finding of ${ }^{14,15,16}$.

Fig.1 Estimation of growth curves of Etroplu suratensis using ELEFAN-1

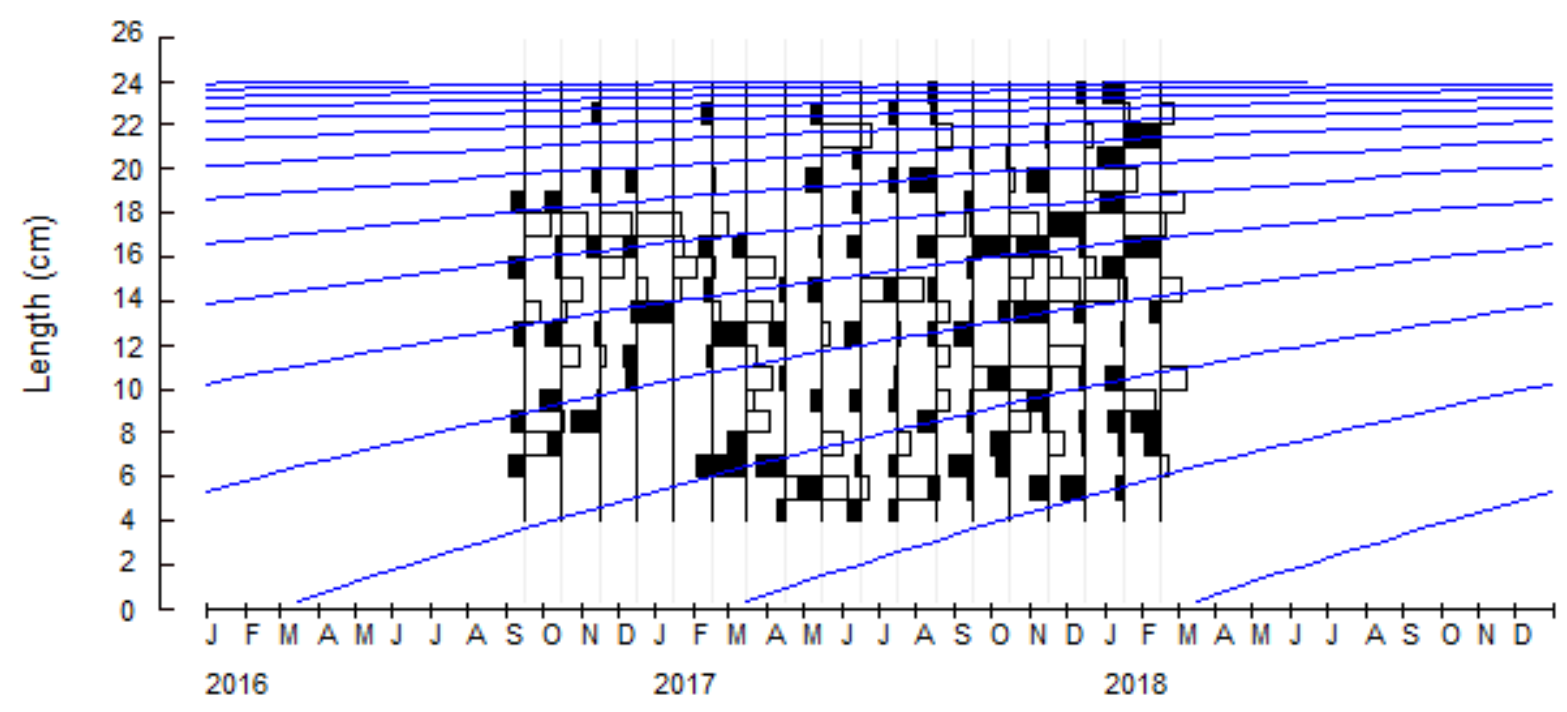

Fig.2\&3 Estimation of 'M' using Pauly's empirical equation \& Estimation of probability of capture using length converted catch

Jones and van Zalinge Plot
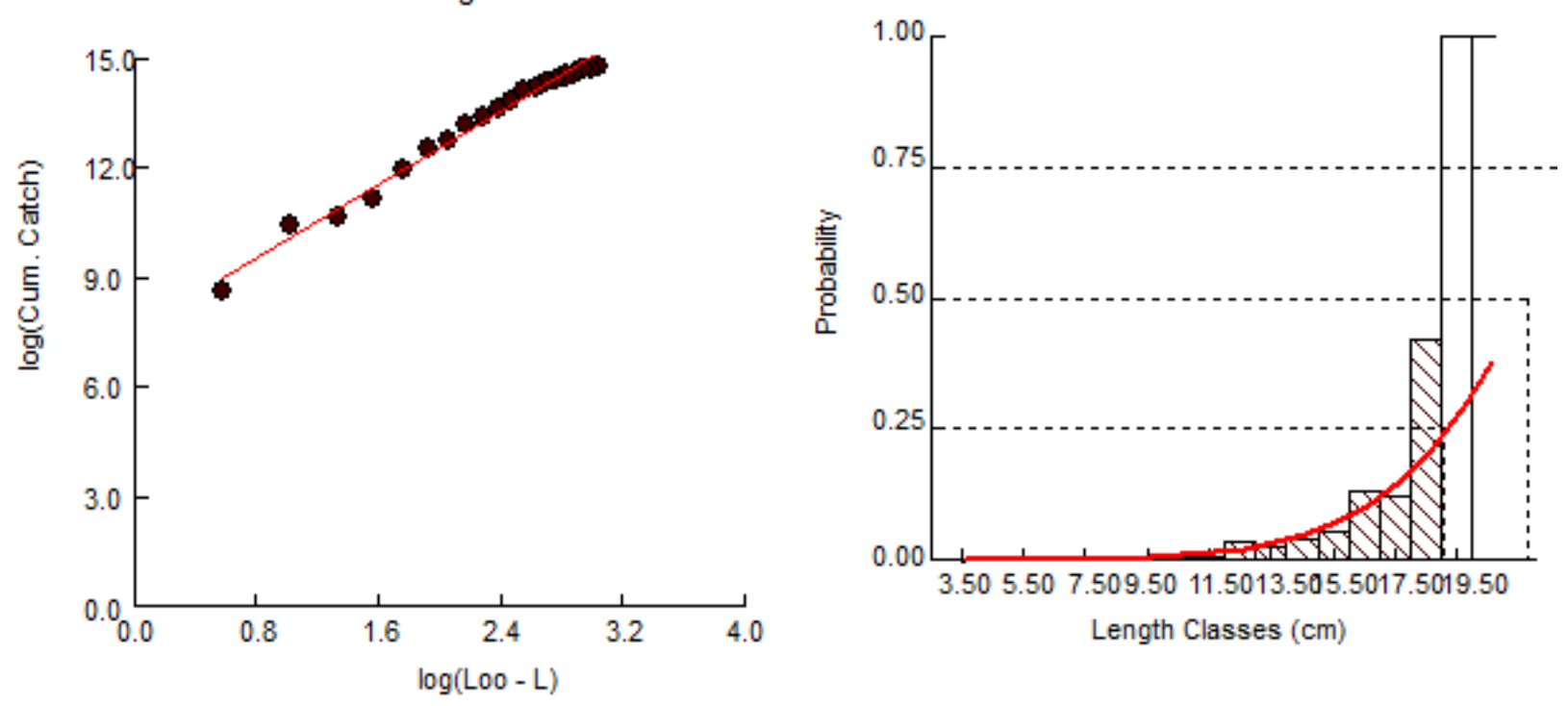
Fig.4\&5 Estimation of recruitment pattern using ELEFAN II \& Relative Y/R and biomass per recruit

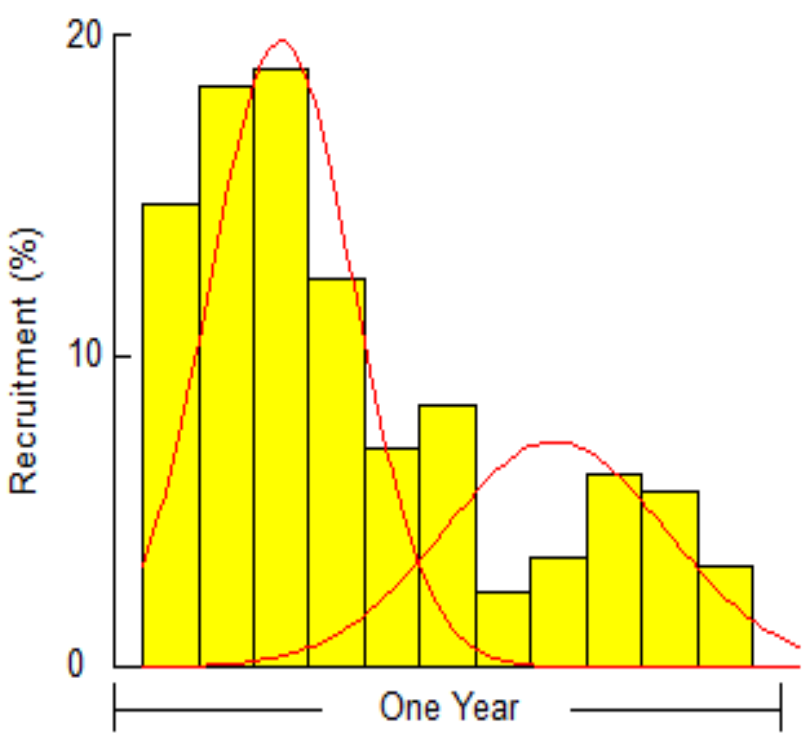

Probability of capture

The probability of capture was estimated from the length converted catch curve using the FiSAT-II (FAO-ICLARM Stock Assessment Tools) From the probability of capture it was found that $\mathrm{L}_{25}, \mathrm{~L}_{50}$ and $\mathrm{L}_{75}$ as 19.06 $\mathrm{cm}, 21.75 \mathrm{~cm}$ and $24.45 \mathrm{~cm}$ respectively which indicates that the at $19.06 \mathrm{~cm}$ length $25 \%$ of the fish will be vulnerable to the gear (left hand selection), at $21.75 \mathrm{~cm} 50 \%$ of the fish will be vulnerable to the gear (left hand selection) and at $24.45 \mathrm{~cm} 75 \%$ of the fish will be vulnerable to the gear (left hand selection) (Fig. 3). Similar results also reported by ${ }^{17,18,19}$.

\section{Recruitment pattern}

The recruitment pattern was determined through the ELEFAN II analysis ${ }^{20}$ with the separation of normal distributions of the peaks by means of the NORMSEP program. Figure 4 show indicates the recruitment patterns of E.suratensis indicating two annual recruitment, the first recruitment occurred

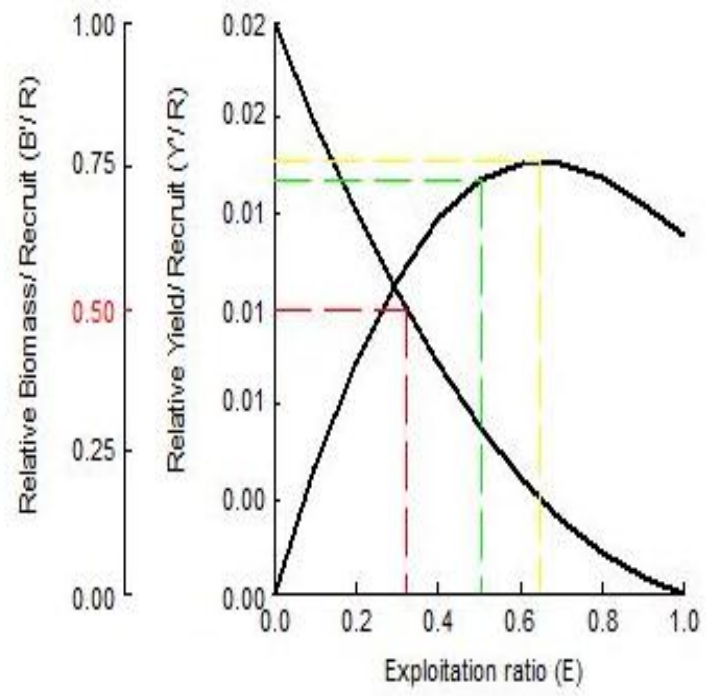

between January to April with a sharp peak in March accounting (18.93\%) of the total catch and the second small one occurred between July to September with a sharp peak in June accounting $(8.22 \%)$ of the total catch. The results of two pulses of recruitment also reported by ${ }^{21,22,23,24}$.

\section{Yield-per-recruit and biomass-per-recruit}

The relative yield-per-recruit (Y/R) and biomass-per-recruit $(\mathrm{B} / \mathrm{R})$ were deter-mined as a function of $L_{c} / L_{\infty}$ and $M / K$ respectively (Fig. 5). The $\mathrm{L}_{c} / \mathrm{L}_{\infty}$ and the values of $\mathrm{M} / \mathrm{K}$ are 0.350 and 2.86. The exploitation rates $\left(\mathrm{E}_{10}=\right.$ $0.504, \mathrm{E}_{75}=0.322, \mathrm{E}_{\max }=0.649$ ) for $E$. suratensis. In the $\mathrm{Emax}=0.649$, the $\mathrm{Y} / \mathrm{R}$ value is 0.09 that indicates the $18 \%$ virgin biomass is left. From the present study the exploitation rate as $\mathrm{U}=0.43$ and exploitation ratio calculated as $\mathrm{E}=0.60 .^{(16,25)}$.

From the above study it can be concluded that the present level of exploitation of $E$. suratensi is quite higher than the optimum level of exploitation. So it is recommended to 
reduce the effort at least by $35 \%$ to recover the stock.

\section{Acknowledgement}

The authors would like to acknowledge the Vice Chancellor, Orissa University of Agriculture and Technology OUAT, Bhubaneswar, Odisha and Director College of Fisheries, Rangeilunda for smooth execution of this work.

\section{References}

1. Rishi,K.K. and J.Singh, (1982). Karyological studies on five estuarine fishes. Nucleus, 25(3): 178-180.

2. Prasadam RD,(1971) Observations on the biology of the pearl spot Etroplus suratensis (Bloch) from the Pulicat lake. Madras Journal of Inland Fisheries Society of India.; 3:72-78.

3. Chilika Development Authority (201314). CDA, Odisha, Annual report, 2013 14.

4. Sekharan, K. V. 1962. On oil sardine fishery of the Calicut area during the year 1955- 56 to 1958-59. Indian J. Fish., 9A (2): 679-700.

5. Menon NG, Appanna MS, Sastry Y, Raje SG, Zachariah PU, Ferozkhan M (1992) Stock assessment of marine catfishes in India. Ind J Fish 39(1, 2): 65-84.

6. Murty V, Srinath $\mathrm{M}$, Livingston $\mathrm{P}$, Appannasastry Y, Srinivasarengan $\mathrm{S}$ (1992) Stock assessment of silver bellies of India with particular reference to Andhra Pradesh and Tamil Nadu. Ind J Fish 39(1, 2): 42-64.

7. Miah, M.S., G.C. Haldar and M.A. Rahman. 1997. Estimation of growth and mortality parameters of hilsa, Tenualosa ilisha (Ham.) Population in the Meghna river of Bangladesh. Indian Journal of Fisheries 44(2): 133-39.
8. Mohamed, K. S., and G. S. Rao. 1997. "Seasonal Growth, Stock Recruitment and Prediction of Yield of Indian Squid Loligo duvauceli (d' Orbigny) Exploited from Karnataka Coast." Indian Journal of Fisheries 44: 319329.niloticus) in Lake Victoria, Kenya. Lakes \& Reserv. 2018;23:17-23.

9. Gayanilo, J. and Pauly, D. 1997. The FAO-ICLARM stock assessment tools (FiSAT) reference manual. FAO computerized information series (Fisheries) No:8, FAO, Rome, 262 pp.

10. Pauly D, Munro JL (1984) Once more on growth comparisons in fish and invertebrates. Fishbytes 2 (1): 21.

11. Pauly, D. 1984. Length - converted catch curves: A powerful tool for fisheries research in the tropics (Part II). Fishbyte, 2 (91): 17-19.

12. Gulland JA (1971) The fish resources of the oceans. West by fleet survey. Fishing News (Books) Ltd., for FAO, 255.

13. El-Azab E. B. El-Bokhty (2006) Assessment of family cichlidae inhabiting lake Manzala, Egypt. Egypt. J. Aquat. Biol. \& Fish., Vol. 10, No.4:85 - 106(2006) ISSN 1110 - 6131.

14. Sonan Romuald Assi, Koffi Félix Konan, N'guessan Gustave Aliko1, Koffi Charles Boussou, Kotchi Yves Bony1, Aka Jean-Paul Agnissan and Germain Gourène (2018). Mortality, recruitment pattern and exploitation rates of two Schilbe Oken, 1817 populations: Schilbe mandibularis and Schilbe intermedius from the Aghien Lagoon; estuarine system of West Africa. International Journal of Fisheries and Aquaculture. Vol. 10(4), pp. 44-52.

15. Kemunto C. Sunda, Albert Getabu and James Njiru,(2017). Growth, mortality and exploitation rate of Barbus 
altianalis of River Kuja, Lake Victoria Basin, Kenya.

16. Prasad, G., A. Ali, M. Harikrishnan and R. Raghavan (2012). Population dynamics of an endemic and threatened Yellow Catfish Horabagrus brachysoma (Günther) from Periyar River, southern Western Ghats, India. Journal of Threatened Taxa 4(2): 2333-2342.

17. Sara, J.R, Weyl, OLF, Marr S.M., Smit, W.J,, Fouche PSO and Luus-Powell1, W.J. (2017) Gill net catch composition and catch per unit effort in Flag Boshielo Dam, Limpopo Province, South Africa. Water SA. Vol 43, No 3.pp 463-469.

18. Iwasaki S. Estimation of Demographic Change in Fishing Population for Fisheries Management in Chilika Lagoon, India: A MicroDemographic Approach. Oceanogr Fish Open Access J. 2016; 1(1): 555554.

19. Merilä, Juha. (2015). Baiting improves CPUE in nine-spined stickleback (Pungitius pungitius) minnow trap fishery. Ecology and Evolution. 5. 10.1002/ece3.1635.

20. Pauly D, David N (1981) ELEFAN-I basic program for the objective extraction of growth parameters from length frequency data. Meeresforsch 28(4): 205-211.

21. Yongo E, Agembe S, Outa N, Owili M. (2018). Growth, mortality and recruitment of Nile perch ( Lates Niloticus ) in Lake Victoria, Kenya. Lakes \& Reserv.2018;23:17-23.

22. Sunda KC, Getabu A, Njiru J. 2017. Growth, mortality and exploitation rate of Barbus altianalis of River Kuja, Lake Victoria Basin, Kenya. International Journal of Tropical Hydrobiology and Fisheries; 1: 01-07.

23. Mahmoud, Hatem H., Ezzat Altaf A., Ali T. El-Sayed, Samman Abeer El (2013) Fisheries management of cichlid fishes in Nozha Hydrodrome, Alexandria, Egypt. Egyptian Journal of Aquatic Research (2013) 39, 283-289

24. Kannan A. Pon Saravana, Kumar M. Raj and Venkataramani V.K(2014). Age and growth study of Etroplus suratensis (Bloch, 1790) western ghats of Tamiraparani river, India. Eco. Env. \& Cons. 20 (4): pp. (1825-1828)

25. Yongo E, Agembe S, Outa N, Owili M. Growth, mortality and recruitment of Nile perch (Lates niloticus) in Lake Victoria, Kenya. Lakes \& Reserv. 2018; 23: 17-23.

\section{How to cite this article:}

Samantaray, B.R., S.K. Bhuyan, S.K. Misra and Sathpathy, D. 2019. Study on Mortality and Recruitment Pattern of Etroplus suratensis (Bloch, 1790) from Chilika Lagoon,Odisha. Int.J.Curr.Microbiol.App.Sci. 8(02): 665-670. doi: https://doi.org/10.20546/ijcmas.2019.802.075 